Historic, Archive Document

Do not assume content reflects current scientific knowledge, policies, or practices. 



\section{THE HOME OF ASTERS}

where the question of

\section{QUALITY IS OF UTMOST IMPORTANCE}

Grow the best asters; they occupy no more space and require no more labor.

\section{NEW PRICE LIST FOR THE 1919 CROP}

The prices in this list cancel all previous offers and hold good until October 1, 1920.

\section{The Most Popular Early and Medium Early Asters}

Daybreak-Exquisite shade of light pink. Ounce $\$ 2.75,1 / 2$ oz. $\$ 1.40 ; 1 / 4$ oz. $75 \mathrm{c} ; 1 / 8$ oz. $40 \mathrm{c}$.

Queen of the Market-First early and a profuse bloomer in white, light pink, lavender and purple. Ounce $\$ 2.00,1 / 2$ oz. $\$ 1.05,1 / 4$ oz. $55 \mathrm{c}, 1 / 8$ oz. $30 \mathrm{c}$.

Pets 1 - T pure whit of great beauty. Extra fine strain and a shy seeder. Ounce $\$ 2.75,1 / 2$ oz. $\$ 1.40$, $1 / 4$ oz. $75 \mathrm{c}, 1 / 8$ oz. $40 \mathrm{c}$.

The Royal-Vigorous and productive. White, shell pink, rose pink, lavender and purple. Ounce $\$ 2.50$, $1 / 2$ oz. $\$ 1.30,1 / 4$ oz. $75 \mathrm{c}, 1 / 8$ oz. $40 \mathrm{c}$.

Lavender Gem-The very best early lavender. Ounce $\$ 3.00,1 / 2$ oz. $\$ 1.55,1 / 4$ oz. $80 \mathrm{c}, 1 / 8$ oz. $45 \mathrm{c}$.

\section{The Leading Mid-Season Comet Asters}

Improved Rochester-Among the finest in white, lavender pink, shell pink, lavender and purple. Ounce $\$ 2.50,1 / 2$ oz. $\$ 1.30,1 / 4$ oz. $75 \mathrm{c}, 1 / 8$ oz. $40 \mathrm{c}$.

Giant Comet-A well known Comet type, in white, rosy lilac, azure blue. Ounce $\$ 2.00,1 / 2 \mathrm{oz} . \$ 1.05$, $1 / 4$ oz. $55 \mathrm{c}, 1 / 8$ ounce $30 \mathrm{c}$.

White Fleece-Perfect flowers of glistening white. Ounce $\$ 2.00,1 / 2$ oz. $\$ 1.05,1 / 4$ oz. $55 \mathrm{c}, 1 / 8$ oz. $30 \mathrm{c}$.

Astermum-A select strain of this aster in white pink and purple. Ounce $\$ 2.50,1 / 2 \mathrm{oz} . \$ 1.30,1 / 4 \mathrm{oz}$. $75 \mathrm{c}$, 18 oz. $40 \mathrm{c}$.

Triumph Comet-A magnificent new class of midseason Aster, in white and shell pink. Ounce $\$ 2.50$, $1 / 2$ oz. $\$ 1.30,1 / 4$ oz. $75 \mathrm{c}, 1 / 8$ oz. $40 \mathrm{c}$.

\section{Unequaled Assortment of Superior Mid- Season to Late Asters}

Improved Giant Crego-One of the best Asters for florists now in cultivation. Colors, white, shell pink, rose pink, lavender and purple. Ounce $\$ 2.75$, $1 / 2$ oz. $\$ 1.40,1 / 4$ oz. $75 \mathrm{c}, 1 / 8$ oz. $40 \mathrm{c}$.

Pacific Beauty-The finest lavender of the Comet type. Ounce $\$ 3.00,1 / 2$ oz. $\$ 1.55,1 / 4$ oz. $80 \mathrm{c}, 1 / 8$ oz. $45 \mathrm{c}$.

Dreer's Super Irate Branching-A careful selection of this well known aster. White, shell pink, rose pink, lavender, azure blue and purple. Ounce $\$ 2.00,1 / 2$ oz. $\$ 1.05,1 / 4$ oz. $55 \mathrm{c}, 1 / 8$ oz. $30 \mathrm{c}$.
Peerless Iate Branching-By far the best of all the late branching asters. Colors, white, shell pink rose pink, and purple. Ounce $\$ 2.75,1 / 2$ oz. $\$ 1.4 v$, $1 / 4$ oz. $75 \mathrm{c}, 1 / 8$ oz. $40 \mathrm{c}$.

Giant Crimson-A dark velvety crimson which attracts much attention. Ounce $\$ 1.50,1 / 2$ oz. $80 \mathrm{c}$, $1 / 4$ oz. $45 \mathrm{c}, 1 / 8$ oz. $25 \mathrm{c}$.

Crimson King-A well known aster of special merit. Ounce $\$ 3.00,1 / 2$ oz. $\$ 1.55,1 / 4$ oz. $80 \mathrm{c}, 1 / 8$ oz. $45 \mathrm{c}$.

\section{New Asters for 1920}

Sold this year in packets only containing about $1 / 16$ ounce each at $50 \mathrm{c}$ per packet.

Iavender Pink Peerless-Same shade as Lavender Pink Rochester.

Azure Blue Peerless-A deep rich lavender

Azure Blue Astermum-Beautiful shades of azure blue.

The above new asters being only new in color and the same in type as asters already introduced it seems practical to list them as such and thereby avoid much confusion.

\section{A Great Future for Asters}

Very few persons, even in the trade, appreciate the real value of the aster, and few growers realize to what mammoth proportions this business can be developed by careful handling. It is only by the most palnstaking effort while making a specialcy of the aster that we were able to get the attention of the critical customer. It is the perfect quality of the mammoth chrysanthemum like blooms which gives the stock prestige over all other asters on the market.

\section{Experience of Value}

In no line of business is the experience which comes with passing time of more benefit than in the production of good asters, and being for years actual producers of all the seed offered for sale in our lists, we feel safe in saying that this stock, if properly handled, will give entire satisfaction to the most critical grower of this popular flower.

\section{Prices Reasonable}

Our prices are as reasonable as good seed can be produced; and the utmost care is used in the selecting, roguing, harvesting and threshing of this stock. Prices, however, should be the last thing to consider when buying seeds. If you regard results taking into consideration the high cost of labor of today, land value, loss of time and injury to trade along with minor disappointments accompanying crop failures, no price would be considered too high to pay for good seed.

\section{Eastern Customers}

Atlantic coast customers who do not wish to send so far for their seed can now obtain the $H$. \& $F$. Quality Aster Seed in original packets from Roman J. Irwin, 108 West 28 th Street, New York City.

\section{HERBERT \& FLEISHAUER}


